\title{
Transfer Teknologi Pemuliaan Tanaman Cabe (Capsicum annum L) Metode Hibrid Pada SMK Tekung Lumajang Kabupaten Jember, Jawa Timur
}

\author{
Tanti Kustiari $^{1 *}$, Ujang Suryadi ${ }^{2}$, Eli Siswanto ${ }^{3}$ \\ ${ }^{123}$ Manajemen Agribisnis, Politeknik Negeri Jember \\ *e-mail: tanti_kustiari@gmail.ac.id \\ Received: 08 Juli 2020; Revised: 21 Agustus 2020; Accepted: 28 Agustus 2020 \\ DOI: http://dx.doi.org/10.37905/aksara.6.2.97-102.2020
}

\begin{abstract}
Abstrak
Teknologi pemuliaan tanaman cabe merah metode hibrid diperkenalkan pada siswa mempertimbangkan faktor rekayasa genetika dan nilai ekonomis. Tujuannya siswa trampil memproduksi cabe berstandar SNI dan mampu memperbaiki karakteristik galur yang dihasilkan. Metode pelaksanaan adalah pembelajaran dalam kelas dan demonstrasi dengan materi persiapan plasma nutfah, pemeraman benih, persemaian, persiapan media, penanaman, pemeliharaan, pengairan, pemupukan, pengendalian hama dan penyakit, pemeliharaan, hibridisasi panen, penyimpanan benih hasil hibridisasi. Hasil yang diperoleh adalah siswa-siswi trampil melakukan kegiatan pemuliaan tanaman cabe merah dengan metode hibridisasi. Cabe merah hasil persilangan hibridisasi memiliki sifat unggul panjang $13 \mathrm{~cm}$, bentuk normal sesuai standar SNI dan sesuai selera pasar.
\end{abstract}

Kata Kunci : Cabe Merah, pemuliaan, hibrid

\begin{abstract}
Transfers technology of hybrid chili breeding with hybrid methods The aim of the empowerment of the student skill that was to produced chili with SNI standard advantages and being able to improve the characteristics of the lines produced. Activities carried out are classroom learning and demonstrations with germplasm preparation material, seedling, seeding, media preparation, planting, maintenance, irrigation, fertilizing, pest and disease control, maintenance, harvest storage. The results obtained are students who have skilled in conducting red chilli breeding activities with hybridization methods. The characteristic of chili have length of $13 \mathrm{~cm}$, normal shape according to SNI standards and meets market tastes.
\end{abstract}

Key Word : Chili, Breeding, Hybrid

\section{PENDAHULUAN}

Dokumen Sekolah Menengah Kejuruan (SMK) Negeri 1 Tekung Lumajang, Jawa Timur merupakan salah satu sekolah pertanian yang oleh pemerintah di-revitalisasi guna mencapai sekolah pertanian berkualitas dan maju dalam bidangnya. Saat ini SMK Negeri 1 Tekung memiliki program studi baru bidang pemuliaan tanaman yang harus ditempuh selama 4 tahun lama waktu studi. Khususnya siswa-siswi kelas 3 jurusan pemuliaan tanaman pangan dan hortikultura, saatnya diberikan materi pembelajaran pemuliaan tanaman hortikultura. 


$\begin{array}{ll}\text { Volume }: 06 \\ \text { Nomor } & : 03 \\ \text { Bulan } & : \text { September } 2020 \\ \text { Tahun } & : 2020 \\ \text { http } & : / / \text { ejurnal.pps.ung.ac.id/index.php/Aksara }\end{array}$

Permasalahan yang dihadapi sekolah SMK 1 Tekung, pertama adalah tenaga pengajar jurusan pemuliaan tanaman kelas 3 membutuhkan kebaruan ilmu pengetahuan bidang pemuliaan tanaman hortikultura. Guru jurusan pemuliaan tanaman menyadari bahwa diseminasi teknologi pemuliaan tanaman hortikultura dari lembaga pendidikan perguruan tinggi sangat diperlukan untuk menambah wawasan, memutakhirkan penguasaan teknologi bidang pemuliaan tanaman hortikultura.

Permasalahan kedua sebagai dampak langsung dari masalah pertama adalah keterbatasan siswa-siswi mendapatkan pembelajaran pemuliaan tanaman. Permasalahan ketiga, lembaga pendidikan jurusan pemuliaan tanaman di SMK 1 Tekung belum memiliki plasma nutfah sendiri. Selama ini penggunaan benih bersumber dari toko.

Berdasarkan hasil permasalahan di atas, maka lembaga Perguruan Tinggi Polije melalui kegiatan Praktik Pembelajaran dan Pemberdayaan Masyarakat Program Pascasarjana, mengedepankan peran aktif memberikan pemecahan masalah bagi lingkungan masyarakat sekitar. Staf pengajar dan mahasiswa Polije mengawali dengan kegiatan identifikasi permasalahan dan kesepakatan program pemecahan masalah. Program yang disepakati adalah memberikan pelatihan pemuliaan tanaman cabe pada siswa-siswi kelas 3 jurusan pemulihaan tanaman, praktek persilangan tanaman hortikultura untuk menghasilkan tanaman baru yang memiliki karakteristik unggul dengan metode hybridisasi. Tujuannya adalah meningkatnya pengetahuan dan skill SDM siswa-siswi jurusan pemuliaan tanaman pangan dan hortikultura dalam memproduksi sayuran yang memiliki keunggulan berstandar SNI. Siswa-siswi mampu menghitung potensi nilai ekonomi dari hasil perbaikan keunggulan benih. Tersedianya plasma nutfah baru benih cabe yang unggul di sekolah SMK 1 Tekung.

Komoditas yang diperkenalkan pada kegiatan pemuliaan tanaman adalah cabe. Mengapa cabe, dikarenakan cabe mempunyai prospek ekonomi yang menguntungkan, komoditas penting di dunia. Memiliki fungsi sebagai bahan penyedap atau bumbu masakan dan juga dapat dikonsumsi dalam bentuk segar (Duriat,1996) [1]. Selain mengandung zat yang rasanya pedas (capcaisin), cabai juga mengandung provitamin A dan vitamin C (Rubatzky dan Yamaguchi, 1998) [2]. Di samping berbagai kegunaan dalam bidang makanan dan industri, cabai juga banyak dimanfaatkan sebagai tanaman hias taman (Bosland dan Votava, 1999) [3].

Menurut Badan Pusat Statisitik (2018) [4], produksi cabai di Provinsi Jawa timur pada tahun 2018 adalah 100.000 ton. Jawa Timur juga merupakan salah satu wilayah sentra produksi cabai merah di Indonesia yang menempati peringkat empat. Sedangkan tingkat konsumsi masyarakat tidak mencapai 100 gr perkapita perbulan (sekitar 3.500 ton pertahun). Kondisi tersebut sangat memungkinkan untuk cabai merah hasil pertanian Jawa Timur untuk di ekspor ke wilayah lain. Wilayahnya yang strategis di bagian tengah kepulauan Nusantara, menjadi nilai tambah untuk persebaran cabai merah hingga ke wilayah Indonesia bagian tengah.

Komoditas cabe sangat prosfektif karena keberadaannya selalu dibutuhkan masyarakat. Dalam situasi kapan pun, baik situasi harga pasar cabe naik maupun harga menurun, namun cabe selalu dibutuhkan dan dibeli masyarakat. Oleh karena itu pilihan komoditas cabe sangat strategis.

Cabe yang digunakan dalam kegiatan pengabdian mayarakat ini adalah hasil seleksi plasma nutfah CV. Indonesian Seed. Dimana cabe besar ini merupakan hasil 


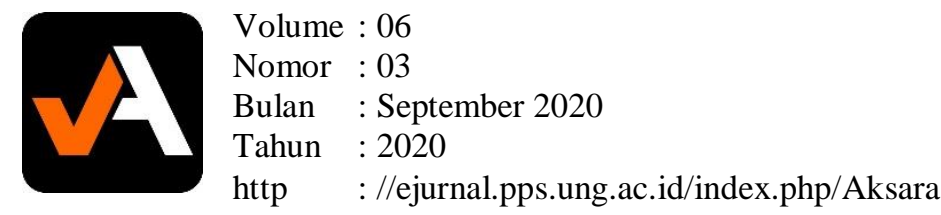

pemurnian dari filial 1 sampai filial 4 . Filial 4 berindikasi stabil ini senada dengan bahwa tanaman yang ditanam dengan perlakuan penyerbukan sendiri dengan 4-5 kali penanaman jika sebaran homozigot dan heterizigot pada satu lokus yang sama diserbuki sampai lima generasi (Syukur, dkk, 2012) [5].

Kegiatan pemuliaan tanaman cabe sebagai suatu usaha untuk meningkatkan keragaman genetik cabe dengan karakter vigor tanaman kokoh dan tegak, warna buah, panjang buah, mudah perawatannya, tahan terhadap penyakit layu bakteri, gemini virus, ,hama thrips, apid dan mite dan umur genjah. Karakter yang sangat penting dalam pemuliaan cabai besar adalah buah besar dengan panjang $12 \mathrm{~cm}$, diameter $14 \mathrm{~cm}$, kulit buah berwarna merah dan mengkilat saat masak. Kegiatan ini diharapkan dapat digunakan untuk mengkaji pola pewarisan warna buah cabai hasil persilangan. Pendugaan pola pewarisan karakter khususnya karakter warna dapat memberikan gambaran tentang metode seleksi yang mungkin diterapkan dalam menangani generasi berikutnya dan dapat diperoleh kombinasi fenotip warna buah cabai baru yang merupakan kombinasi dari kedua tetua hasil persilangan.

Program pengabdian masyarakat pemuliaan tanaman komoditas cabe diharapkan lembaga sekolah memiliki koleksi plasma nutfah dengan nilai ekonomi potensial. Sumberdaya manusia sekolah memiliki kemampuan melakaukan tahapan hibridisasi, tahapan inventarisasi benih. Mampu meningkatkan keragaman genetik baru yang unggul. Mampu memperbaiki calon galur dan varietas baru yang mempunyai keunggulan dan daya saing. Dengan kata lain program PPPK membantu meningkatkan siswa trampil menghasilkan produk benih baru yang mampu bersaing di pasar regional, nasional dan internasional dari SMK Negeri 1 Tekung.

\section{METODE}

1. Definisi Istilah

Plasma nutfah : Materi Pemuliaan

Vaietas : Sekelompok tanaman dari suatu jenis yang ditandai oleh bentuk tanaman, pertumbuhan tanaman, daun, bunga, buah, biji dan eksperesi karakteristik genetic yang sudah stabil.

Hibridisasi : Persilangan tanaman yang dikombinasikan dua tetua tanaman yang berbeda secara genetik

Genetik : Pembawa infomasi gen pada tanaman yang akan dilakukan pelestarian tanaman.

\section{Sejarah Organisasi}

SMK Negeri 1 Tekung MK Negeri 1 Tekung merupakan sekolah yang di-revitalisasi oleh pemerintah guna mengembangkan kualitas sekolah yang maju dalam bidangnya. Kurikulum implementatif merupakan kurikulum yang disusun oleh sekolah dan industri guna menerapkan sistem pendidikan ganda dalam pendidikan kejuruan. Pelaksanaan penyusunan kurikulum implementatif melibatkan sekolah dan industri guna menghasilkan lulusan yang sesuai dengan kebutuhan industri.

SMK Negeri 1 Tekung merupakan lembaga sekolah pertanian yang bergerak di agribisnis tanaman pangan dan hortikultura di bidang budidaya, pemelihaaraan dan pemanenan. Selain itu di bidang pemuliaan tanaman dan perbenihan untuk pembentukan calon benih baru untuk merakit kultivar tanaman yang mempunyai ciri umur panen pendek, tahan terhadap penyakit, dan produksi tanaman tinggi. 


\section{Solusi yang Ditawarkan}

Berdasarkan hasil pengamatan dan identifikasi masalah permasalahan SMK Negeri 1 Tekung adalah belum tersimpannya plasma nutfah baru dan kurangnya tenaga terampil menguasai teknologi persilangan tanaman dengan metode hibridisasi. Metode hibridisasi menjadi acuan akan keberhasilan dan perkembangan siswa untuk merakit tanaman unggul baru.

Oleh karena itu, solusi yang ditawarkan adalah memberikan materi pembelajaran tentang perbaikan kultival baru yang unggul dengan metode hibridisasi. Pemuliaan tanaman untuk memperbaiki plasma nutfah baru dengan produktivitas tanaman cabe terstandard SNI. Selian itu materi penyimpanan plasma nutfah baru. Transfer teknologi pemuliaan tanaman cabe mulai dari persiapan, teknik budidaya yang baik, pengamatan karakter tanaman dan pemanenan ragam genetic oleh siswa-siswi kelas 3 agar mudah mendapatkan varietas unggul baru.

\section{Pendekatan Dan Metode}

Pendekatan pemecahan masalah digunakan untuk memberikan pengertian tentang pemuliaan tanaman dengan metode hibridisasi pada siswa kelas 3 . Tujuannya siswa mampu melaksanakan pemuliaan tanaman cabe dengan metode hibridisasi dengan benar sehinggaa plasma nutfah baru yang dihasilkan memiliki sifat unggul. Plasma nutfah yang digunakan berasal dari Indonesian Seed (IS) yang sudah memiliki berbagai macam galur, harapannya perakitan benih unggul baru berhasil dilakukan. Karakter unggul baru telah melalui uji tanam sampai generasi Filial-4, karakter tersebut memiliki panjang buah $16 \mathrm{~cm}$, diameter 14 berpundak sedang, kulit agak bergelombang, tumpul, buah keras daging buah tebal. Umur panen 80 hari, toleran terhadap antraknose, potensi hasil $2 \mathrm{~kg}$ per tanaman, tanaman sedang, buah tua merah gelap mengkilap, buah muda hijau gelap. Cocok untuk dataran rendah dan tinggi.

Kegiatan pemilihan benih ini telah melalui proses pembentukan parental yang telah di pilih dengan kaidah persilangan hukum mendel dimana keturunan yang memiliki genotype unggul terus di lakukan metode hybrid sampai hybrid tersebut stabil pada generasi keturunan F7. Tentunya keturunan generasi F7 memiliki karakter benih yang unggul dari segi produksi dan tahan hama penyakit. Pemuliaan benih cabe besar ini telah dilakuakn sejak 2017 pada penanaman bulan 7 agustus 2017.

Kegiatan transfer teknologi produksi benih metode hibridisasi meliputi persiapan plasma nutfah, pemeraman benih, persemaian, persiapan media dengan karung, penanaman, pemeliharaan, pengairan, pemupukan, pengendalian hama dan penyakit, pemeliharaan buah hibridisasi, panen, penyimpanan benih hasil hibridisasi.

\section{Tempat dan Waktu Pelaksanaan}

Kegiatan dilaksanakan di Sekolah Menengah Kejuruan (SMK) Negeri 1 Tekung, Kecamatan Tekung, Kabupaten Lumajang, Provinsi Jawa Timur. Waktu pelaksanaan sejak bulan September 2019 sampai dengan bulan November 2019. 
Tabel 1. Jadwal Pelaksanaan Kegiatan Transfer Teknologi Pemuliaan Cabe Merah

\begin{tabular}{|c|c|c|c|}
\hline No & Vaktu & $\mathrm{Ke}$ & Kete \\
\hline 1 & $\begin{array}{l}\text { Minggu ke } \\
\text { (September } \\
\text { 2019) }\end{array}$ & $\begin{array}{l}\text { Persiapan PPPM, } \\
\text { pengenalan, adaptasi } \\
\text { dan }\end{array}$ & $\begin{array}{l}\text { Observasi kegiatan produksi serta } \\
\text { mengumpulkan temuan masalah yang } \\
\text { ada. }\end{array}$ \\
\hline 2 & $\begin{array}{l}\text { Minggu ke } \\
\text { (September } \\
\text { 2019) }\end{array}$ & $\begin{array}{l}\text { Konsultasi dengan } \\
\text { sekolah }\end{array}$ & $\begin{array}{l}\text { Beberapa temuan masalah yang ada } \\
\text { dilakukan konsultasi dengan guru } \\
\text { kejuruan pertanian SMK Negeri } 1 \\
\text { Tekung. }\end{array}$ \\
\hline 3 & $\begin{array}{l}\text { Minggu ke } \\
\text { (September } \\
\text { 2019) }\end{array}$ & $\begin{array}{l}\text { Perumusan masalah } \\
\text { dan rencana desain } \\
\text { penyelesaian }\end{array}$ & $\begin{array}{l}\text { lan masalah yaitu bahan plasma } \\
\text { h yang belum ada dan tenaga } \\
\text { pil. } \\
\text { han teknik produksi pemuliaan } \\
\text { han hortikultura dengan metode } \\
\text { lisasi. }\end{array}$ \\
\hline 4 & $\begin{array}{l}\text { Minggu ke } \\
\text { (September } \\
\text { 2019) }\end{array}$ & in proposal & $\begin{array}{l}\text { ngan dengan dosen pembimbing } \\
\text { terkait dengan proposal yang } \\
\text { diseminarkan di SMK Negeri } 1 \\
\text { g. }\end{array}$ \\
\hline 5 & $\begin{array}{l}\text { Minggu ke } 1 \\
\text { (Oktober 2019) }\end{array}$ & $\begin{array}{l}\text { Pelal } \\
\text { Semi }\end{array}$ & $\begin{array}{l}\text { Dilakukan di SMK Negeri } 1 \\
\text { Tekung.yang } \\
\text { pembimbing dari pihak Politeknik } \\
\text { Negeri Jember. }\end{array}$ \\
\hline 6 & $\begin{array}{l}\text { (Minggu ke 2\& } \\
3 \text { Oktober 2019) }\end{array}$ & $\begin{array}{l}\text { Pelal } \\
\text { Impl } \\
\text { Prop }\end{array}$ & $\begin{array}{l}\text { Melibatkan langsung pihak siswa, } \\
\text { guru SMK Negeri } 1 \text { Tekung baik } \\
\text { dalam pelatihan, membuat alternatif } \\
\text { pemecahan masalah dalam } \\
\text { pengkodean plasma nutfah baru yang } \\
\text { baik dan benar sesuai dengan realita } \\
\text { yang ada di lapangan }\end{array}$ \\
\hline 7 & $\begin{array}{l}\text { Minggu ke } 4 \\
\text { (Oktober 2019) }\end{array}$ & $\begin{array}{l}\text { In data } \\
\text { tanaman }\end{array}$ & $\begin{array}{l}\text { Membuat catatan karakter tanaman } \\
\text { meliputi morfologi tanaman tiap kode } \\
\text { crops plant }\end{array}$ \\
\hline 8 & $\begin{array}{l}\text { Minggu ke } 1 \& 2 \\
\text { (November } \\
\text { 2019) }\end{array}$ & $\begin{array}{l}\text { Melakukan } \\
\text { persilangan } \\
\text { (Hibridisasi) }\end{array}$ & $\begin{array}{l}\text { Pemberian penyuluhan teknik } \\
\text { hibridisasi yang benar. }\end{array}$ \\
\hline 9 & $\begin{array}{l}\text { Minggu ke } 3 \\
\text { (November } \\
\text { 2019) }\end{array}$ & $\begin{array}{l}\text { Pemanenan kode } \\
\text { tiap tanaman }\end{array}$ & $\begin{array}{l}\text { Pemanenan dengan pemberian kode } \\
\text { tiap galur yang telah di lakukan } \\
\text { hibridisasi. }\end{array}$ \\
\hline 10 & $\begin{array}{l}\text { (Minggu ke } \\
\text { November } \\
\text { 2019) }\end{array}$ & $\begin{array}{l}\text { Penyimpanan } \\
\text { produk benih ba } \\
\text { hasil Hibridisasi. }\end{array}$ & $\begin{array}{l}\text { Penyimpanan benih dan data harus } \\
\text { lengkap sekaligus sosialisasi kepada } \\
\text { SMK Negeri } 1 \text { Tekung. }\end{array}$ \\
\hline
\end{tabular}

Sumber : Data Primer, 2019 


\section{Hasil dan Pembahasan \\ Hasil Kegiatan}

Kegiatan pengabdian pada masyarakat dilaksanakan di Sekolah Menengah Kejuruan (SMK) Negeri 1 Tekung, Kecamatan Tekung, Kabupaten Lumajang, sejak bulan September 2019 sampai dengan bulan November 2019. berikut ini tahapan kegiatankegiatannya :

\section{a. Persiapan Plasma Nutfah}

Plasma nutfah yang digunakan untuk kegiatan perakitan tanaman baru di SMK Negeri 1 Tekung merupakan hasil dari koleksi INDONESIAN SEED (IS) yang dilakukan dari persilangan galur-galur tanaman yang sudah homozigot. Tanaman homozigot merupakan tanaman dari persilangan antara tetua jantan dan betina selanjutnya dilakukan persilangan sendiri (selfing). Plasma nutfah yang digunakan memiliki karakteristik produktivitas tinggi, daya hasil, daya simpan lebih lama, kualitas buah sesuai selera konsumen. Harapannya pemuliaan tanaman cabe dapat mencapai standar SNI grade 1.

\section{b. Budidaya Tanaman Cabe}

Seluruh siswa kelas 3 mengikuti kegiatan budidaya cabe secara bertahap, yaitu

(1) penyiapan media semai dengan cara mencampur hasil ayakan cocopeat dan pupuk kandang dengan perbandingan $2: 1$, ditambah NPK dan fungisida Victory. Kemudian dimasukkan ke dalam plastik semai.

(2) pemeraman benih dengan air hangat selama 2 jam untuk pemecahan dormansi. Benih diberi kode dan diperam dalam lemari dilengkapi dengan lamput 20 watt.

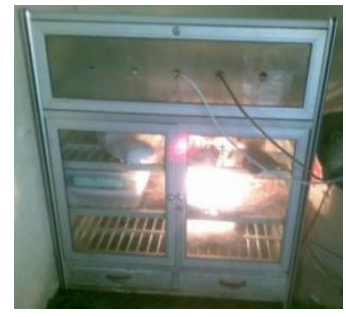

Gambar 1. Germinator

(3) Persemaian di dalam greenhouse.

(4) penanaman dengan cara memberi kode tiap karung sesuai kode tanaman. Kemudian pemeliharaan, disiram setiap hari dan diberi pupuk.

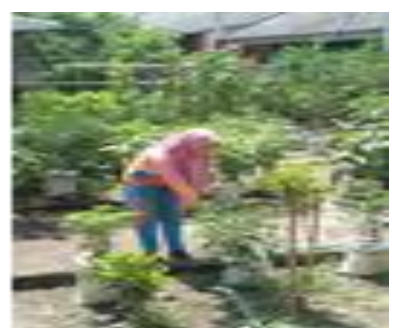

Gambar 2. Pengairan dan Pemupukan

(5) Penyulaman mengganti tanaman yang mati, layu, kurang baik dilakukan hingga tanaman usia 1 mst. Dilanjutkan dengan pemasangan ajir dan tali pengikat. 


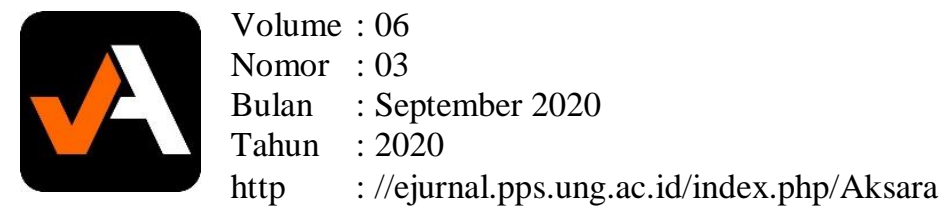

(6) Pembumbunan yaitu menutup akar yang ke luar ke permukaan. Tujuanya mengokohkan tanaman.

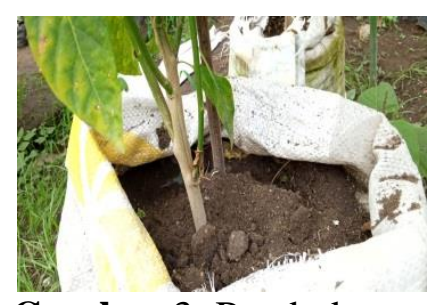

Gambar 3: Pembubunan

(7) Penyiangan tanaman dari gulma yang tumbuh di sekitarnya.

(8) Pengendalian hama dan penyakit secara terpadu dengan cara menjaga kebersihan, menghancurkan tanaman inang, tanaman yang rusak akibat OPT.

(9) Pemelihraan buah umur sekitar 85-90 hst. Buah berubah dari warna hijau menjadi merah.

(10) Panen dilakukan tiap minggu sekali dengan tingkat kemasakan sekitar $80 \%$. kemudian dipisahkan buah dengan kualitas baik dari buah yang kurang baik.
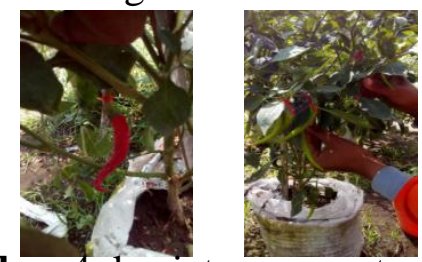

Gambar 4. kegiatan panen tanaman cabai

\section{c. Hibridisasi (persilangan)}

Kegiatan hibridisasi diawali dengan isolasi atau menutup bunga cabe yang telah siap sehari sebelum dipolinasi. Tanda bunga cabe yang siap untuk dipolinasi adalah mahkota bunga masih menguncup dan berwarna putih dan mekar. Cabe yang diisolasi atau ditutup dengan sedotan agar tidak terjadi penyerbukan oleh serangga.

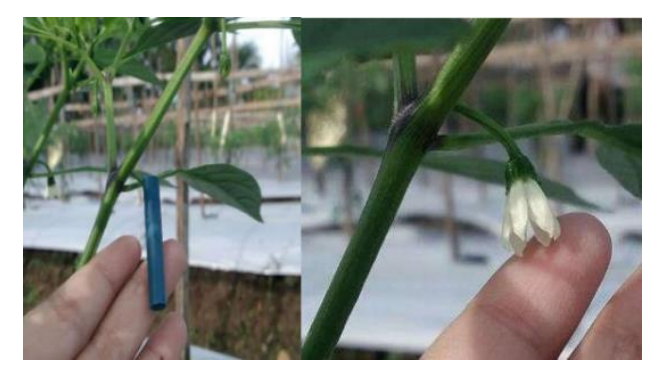

Gambar 5. Bunga Cabe Betina yang Diisolasi

Persilangan bunga cabe adalah proses mempertemukan antara serbuk sari dengan kepala putik untuk tujuan menhasilkan varietas yang berbeda dari induknya. Persilangan siap dilakukan 30 hari setelah tanaman dimana sudah terdapat ruas cabang pertama. Bunga pada ruas pertama tidak disilangkan, karena dapat menghambat laju unsur hara dari dalam tanah. Persilangan dilakukan dari ruas kedua. 


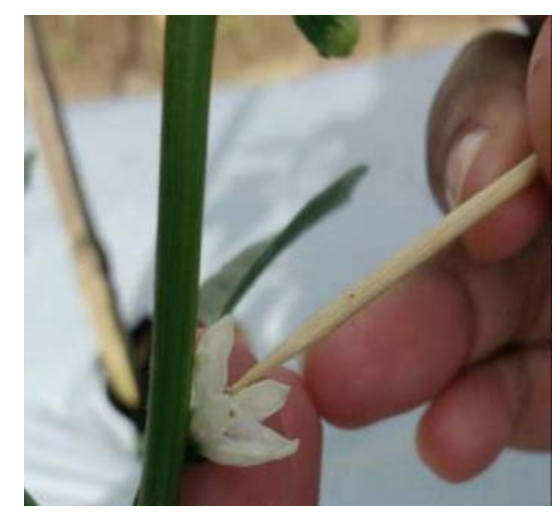

Gambar 6. Persilangan Tanaman Cabe

\section{d. Inventarisasi dan Penyimpanan Benih}

Buah Buah cabai hasil breeding yang telah dipanen, diekstraksi kering yaitu memisahkan biji dari bagian buah lainnya. Biji-biji tersebut dipisahkan setiap kode dan dimasukkan ke dalam kantong strimin.kemudian dituliskan kode-kode berupa kode lapang, nomor tanaman, lokasi, blok, dan tanggal panen.

Benih tersebut, dipilah antara benih yang penampakannya baik dan jelek. Dalam sortasi juga dipisahkan dari kotoran-kotoran seperti kerikil atau bagian-bagian lain dari buah. Selanjutnya ditimbang.

Kegiatan inventarisasi atau pencatatan benih induk ke dalam buku induk benih berisi informasi tentang kode lapang, nomor tanaman, tanggal panen, jumlah pack, dan total berat benih.

Benih yang telah di inventarisasi lalu dimasukkan ke dalam cool room untuk menjaga viabilitas (daya kecambah) benih. Suhu dalam ruangan $20-23{ }^{\circ} \mathrm{C}$ dengan kadar air benih $\pm 7 \%$, kelembaban 30-40\% dan lama penyimpanan kira-kira 2 tahun.

\section{Pembahasan}

Kegiatan pengabdian masyarakat selama 3 bulan di SMK Negeri 1 Tekung Lumajang mampu membawa perubahan yang positif dan sangat bermanfaat untuk sekolah pertanian, yang mana awalnya hanya sebatas sekolah pertanian konvensional tanpa tahu apa sebenarnya pemuliaan tanaman yang harus dilakukan maka dengan pembelajaran dan pelatihan cabe besar metode hibridisasi berhasil menyilangkan tanaman dengan kaidah keilmuan breeding.

Kegiatan Pengabdian Masyarakat mampu memperbaiki penyimpanan koleksi benih dari hasil budidaya dan tahapan pemuliaan cabe besar terutama sumber daya manusia yang tergabung dalam program studi Pemuliaan Tanaman dan Perbenihan Tanaman program 4 tahun agar siswa SMK Negeri 1 Tekung sudah bisa memahami deskripsi kompetensi pada tahapan pengembangan benih baru.

Transfer teknologi melalui kegiatan ceramah, diskusi dan demonstrasi pada kegiatan pemuliaan dan perbenihan tanaman lebih efektif karena kegiatan dan prosedur kerja sudah jelas terbagi pada masing-masing bagian keilmuaan pemuliaan tanaman sehingga semua siswa secara optimal dapat melakukannya. Koordinasi yang baik antara guru, pembimbing siswa dan siswa tertata dengan baik tanpa ada yang diberatkan dengan pada tahapan pemuliaan tanaman cabe besar. 


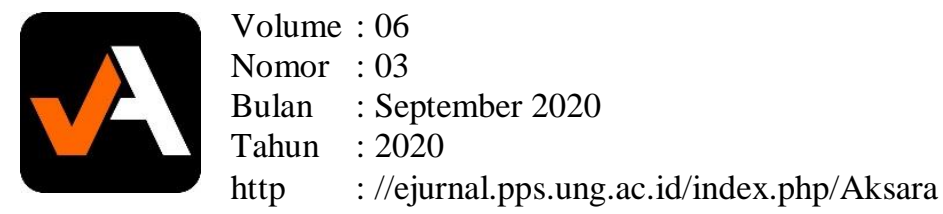

Manajemen prosedur kerja dari budidaya, tahapan pemuliaan dengan hibridisasi, dan tahapan inventarisasi benih breeding tertata dengan baik. Dokumen tersusun dan tersimpan dengan rapi serta mudah dalam pengambilannya apabila sewaktu-waktu benih dibutuhkan untuk Evaluasi hasil Filial 1 (F1). Persedian stok bahan baku sampai produk terkendali dengan adanya pencatatan kode tanaman. Pemasukan dan pengeluaran benih telah bisa adanya pencatatan benih hasil pengkodean pada tiap-tiap nomer kode produksi dengan baik. Adanya tambahan tahapan inventarisasi benih breeding mampu menambah pengetahuan siswa dengan dalam meningkatkan kualitas benih. Sehingga dengan pelatihan dan demonstrasi ini maka siswa di SMK Negeri 1 Tekung menjadi lebih efektif, efiesien dan pengetahuan meningkat.

\section{Hasil Panen Cabe sesuai SNI Grage 1}

Produktivitas tanaman merupakan prioritas utama. Produktivitas cabe yang dipanen berhubungan dengan tingkat pendapatan yang akan diperoleh. Dengan semakin tinggi produktivitas cabe maka pendapatan yang diperolah akan semakin tinggi.

Selain faktor produktivitas yang menjadi pertimbangan pemuliaan tanaman hortikultura, maka pengembangan benih cabe juga harus diupayakan mencapai memliki sifat-sifat yang diinginkan pasar. Panjang buah cabe merupakan salah satu karakter yang banyk diminati konsumen atau petani cabe.

Standar SNI komoditas cabe dapat dijadikan standar hasil cabe yang telah dipanen. Berikut ini parameter atau kriteria kualitas cabai merah menurut SNI grade 1, grade 2, grade 3 [6] dibandingkan dengan hasil panen cabe. Benih cabe yang berhasil dilakukan persilangan metode hibridisasi meliputi yaitu benih cabe CA 001, CA 001a, CA 002, CA 003, CA 004.. benih cabe memiliki sifat atau karakteristik sesuai persyaratan terstandar. Secara terinci dapat dilihat pada Tabel 2.

Hasil panen cabe memenuhi standar SNI grade 1. Selain itu, hasil panen panjang 13 cm juga memenuhi selera pasar sehingga dapat dikatakan karakteristik benih cabe baru telah berhasil mencapai nilai ekonomi. Cabe tersebut berpeluang dapat bersaing dengan benih-benih cabe lainya.

Harapan pengembangan hybrid cabe ini dikategorikan calon bibit unggul dengan mutu produktivitas yang tinggi. Sehingga calon benih ini dapat menghasilkan sayur cabe besar yang baik jika ditanam mampu mencapai $1 \mathrm{~kg}$ per pohon, penanaman cabe mengunakan varietas unggul yang mempunyai produktivitas tinggi dapat meningkatkan produktivitas potensi hasil pertanaman. Sebagai ilustrasi pada lahan yang sempit $(100 \mathrm{~m} 2)$ dengan populasi 300 tanaman jika produktivitas pertanaman mencapai $1 \mathrm{~kg}$ maka hasil yang diperoleh sebanyak $300 \mathrm{~kg}$. 
Tabel 2. Kualitas Cabai Merah Segar Berdasarkan Standar Nasional Indonesia (SNI 01-44801998)

\begin{tabular}{|c|c|c|c|c|c|}
\hline \multirow[t]{3}{*}{$\underline{\text { No }}$} & \multirow[t]{3}{*}{ Jenis Uji } & \multicolumn{3}{|c|}{ Persyaratan SNI } & \multirow{3}{*}{$\frac{\begin{array}{c}\text { Hasil } \\
\text { Panen }\end{array}}{\text { Rata-rata }}$} \\
\hline & & & & & \\
\hline & & Mutu 1 & Mutu II & Mutu III & \\
\hline$\underline{1}$ & $\underline{\text { Keseragaman warna }}$ & $\begin{array}{l}\text { Merah > } \\
95 \%\end{array}$ & $\begin{array}{l}\text { Merah } \\
95 \%\end{array}$ & $\begin{array}{l}\text { Merah } \geq \\
95 \%\end{array}$ & Merah > 95\% \\
\hline$\underline{2}$ & $\underline{\text { Keseragaman }}$ & $\begin{array}{l}\text { Seragam(98 } \\
\%)\end{array}$ & $\begin{array}{l}\text { Seragam } \\
(96 \%)\end{array}$ & $\begin{array}{l}\text { Seragam(95 } \\
\%)\end{array}$ & $\begin{array}{l}\text { Seragam } \\
(98 \%)\end{array}$ \\
\hline$\underline{3}$ & $\underline{\text { Keseragaman }}$ & $98 \%$ normal & $96 \%$ normal & $95 \%$ normal & $98 \%$ normal \\
\hline$\underline{4}$ & $\begin{array}{l}\text { Keseragaman } \\
\text { ukuran } \\
\text { a. Cabe merah besar } \\
\text { - Panjang buah } \\
\text { - Garis tengah } \\
\text { pangkal }\end{array}$ & $\begin{array}{l}12-14 \mathrm{~cm} \\
1.5-1.7 \mathrm{~cm}\end{array}$ & $\begin{array}{l}09-11 \mathrm{~cm} \\
1.3-1.5 \mathrm{~cm}\end{array}$ & $\begin{array}{l}<09 \mathrm{~cm} \\
<1.3 \mathrm{~cm}\end{array}$ & $\begin{array}{l}12-13 \mathrm{~cm} \\
1.5-1.6 \mathrm{~cm}\end{array}$ \\
\hline & $\begin{array}{l}\text { b. Cabe merah } \\
\text { keriting } \\
\text { - Panjang buah } \\
\text { - Garis tengah } \\
\text { pangkal }\end{array}$ & $\begin{array}{l}>12-17 \mathrm{~cm} \\
>1.3-1.5 \mathrm{~cm}\end{array}$ & $\begin{array}{l}10-12 \mathrm{~cm} \\
1.0-1.3 \mathrm{~cm}\end{array}$ & $\begin{array}{l}<10 \mathrm{~cm} \\
<1.0 \mathrm{~cm}\end{array}$ & $\begin{array}{l}>12-15 \mathrm{~cm} \\
>1.3-1.4 \mathrm{~cm}\end{array}$ \\
\hline$\underline{5}$ & Kadar kotoran & 1 & 2 & 5 & 1 \\
\hline$\underline{6}$ & $\begin{array}{l}\text { Tingkat kerusakan } \\
\text { a. Cabe merah besar } \\
\text { b. Cabe merah } \\
\text { keriting }\end{array}$ & $\begin{array}{l}0 \\
0\end{array}$ & $\begin{array}{l}1 \\
1\end{array}$ & $\begin{array}{l}2 \\
2\end{array}$ & $\begin{array}{l}0 \\
0\end{array}$ \\
\hline
\end{tabular}

Sumber : Data Primer Diolah, 2019

\section{Potensi Nilai Ekonomi Cabe Grade 1}

Potensi produktivitas cabe hibrida mencpai $1,2 \mathrm{~kg} / \operatorname{tanaman} / \mathrm{musim}$ tanam. Potensi harus ditunjang oleh kualitas buah yang baik seperti ukuran, penampilan kulit dan kepedasan. Maka dilihat dari kelayakan usaha potensi ekonomi dengan hasil produksi cabe perpohon $1 \mathrm{~kg}$ dengan harga cabe mutu $1 \mathrm{Rp} 26.000,00$ dan biaya perpohon $\mathrm{Rp}$ 7.200,00 maka R/C adalah 3,6. Maka potensi cabe yang dimuliakan ini memiliki nilai keuntungan yang dapat diteruskan.

\section{Simpulan}

Transfer teknologi pemuliaan tanaman cabe merah telah dilaksankaan dengan baik melalui kegiatan pembelajaran di dalam kelas dan demonstrasi. Teknologi pemuliaan cabe dengan metode hibridisasi dilaksanakan seluruh siswa-siswi kelas 3 jurusan pemuliaan tanaman pangan dan hortikulturan SMK Negeri 1 Tekung dengan baik meliputi tahapan yang sangat teratur mulai penyiapan media semai, pemeraman benih, 


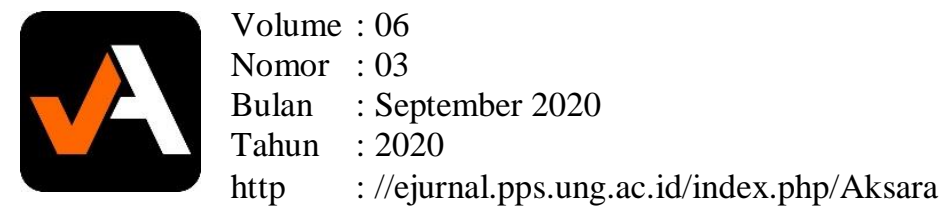

persemaian, persiapan media, penanaman, pemeliharaan, pengendalian hama dan penyakit, pemeliharaan buah dan panen. Tahapan kegiatan hibridisasi dimulai dari pemilihan indukan tetua jantan dan betina, pemberian label/ kode tanaman, pelaksanaan kastrasi dan emaskulsasi dan hibridisasi.Tahapan inventarisasi benih breeding proses ektraksi, packing benih, sortasi, penimbangan dan inventarisasi sesuai kode tetua tanaman dan hasil hibridisasi serta penyimpanan. Hasil cabe yang dipanen memiliki sifat atau karakteristik unggul sesuai stndar SNI grade 1. rata-rata bentuk normal dan ukuran panjang $13 \mathrm{~cm}$ merupakan ciri benih yang banyaka diminati oleh pasar. Kegiatan pemuliaan tanaman tersebut telah menunjukkan bahwa siswa-siswi SMK 1 Tekung telah memiliki pengalaman meningkatkan nilai benih cabe dari hasil persilangan metode hibridisasi. Dari sudut perhitungan analisis usaha, maka perbaikan sifat galur tersebut memiliki potensi ekoonmi sehingga layak untuk dilanjutkan.

\section{Daftar Pustaka}

Duriat, A.S. (1996). Cabai merah : Komoditas Prospektif dan Andalan. Di dalam : Duriat AS, Widjaja WH, Soetiarso TA, Prabaningrum L (ed). Teknologi Produksi Cabai Merah. Lembang, Bandung : Balai Penelitian Tanaman Sayuran Pusat Penelitian dan Pengembangan Hortikultura, Badan Penelitian dan Pengembangan Pertanian. Hlm 1-3

Rubatzky, V. E dan M. Yamaguchi. (1998). Syuran Dunia 1 (terjemahan). Institut Teknologi Bandung.

Bosland, P.W and E.J. Votava. (1999). Pepper : Vegetables and Spice Capsicums. CABI Publishing. UK.

Badan Pusat Statistik. (2018). Distribusi Perdagangan Cabe Merah di Indonesia.ISBN:978-602-438-265-0

Syukur, M., dkk, (2012). Teknik Pemuliaan Tanaman.Jakarta:Penebar Swadaya-cetakan $1+348 \mathrm{hlm}$.

Badan Standarisasi Nasional. 1998. Cabai Merah Segar. Standar Nasional Indonesia (SNI). 
Volume : 06

Nomor : 03

Bulan : September 2020

Tahun : 2020

http : //ejurnal.pps.ung.ac.id/index.php/Aksara

294 AKSARA: Jurnal IImu Pendidikan Nonformal 